\title{
PENGUATAN PERAN PANWASLU DALAM PEMILUKADA (Studi Kasus: Pemilukada Kabupaten Jembrana)
}

\section{STRENGTHENING THE ROLE OF ELECTION SUPERVISORY COMMITTEE IN HEAD REGION ELECTORAL (Case Study: Head Region Electoral of Jembrana)}

\author{
Dedeh Haryati \\ Pusat Pengkajian, Pengolahan Data, dan Informasi (P3DI) Sekretariat Jenderal DPR-RI \\ e-mail: keyshaghinacamila@yahoo.com
}

Diterima: 5 Mei 2012, Direvisi: 10 Mei 2012, Disetujui: 31 Mei 2012

\begin{abstract}
Abstrak
Kajian ini bertujuan untuk mengidentifikasi pelaksanaan tugas dan wewenang Panwaslu dalam pelaksanaan Pemilukada di Kabupaten Jembrana. Metode yang digunakan deskriptif kualitas. Hasil kajian menunjukkan bahwa peran Panwaslu dalam pelaksanaan Pemilukada belum optimal karena belum diberi peran yang luas, masih merupakan lembaga ad hoc, dan pola rekrutmen yang belum baik. Disarankan, agar memperluas kewenangan Panwaslu, pembentukannya bukan sebagai lembaga ad hoc; dan pola rekrutmennya diperketat dengan persyaratan yang memadai.

Kata Kunci: Panwaslu, peran, penguatan.
\end{abstract}

\begin{abstract}
This study aims to identify the tasks and authority in the implementation of the Panwaslu Jembrana District. The method used descriptive quality. The study results showed that the role of the Panwaslu in the implementation of the Pemilukada is not optimal because it has not been given a broad role, is still an ad hoc institution, and the recruitment pattern that has not been good. It is recommended, in order to expand the authority of the Panwaslu, formation rather than as an ad hoc institution, and recruitment patterns tightened the requirements adequately.
\end{abstract}

Keywords: Panwaslu, roles, strengthening.

\section{PENDAHULUAN}

Pemilu adalah sebuah sarana untuk mewujudkan kehendak rakyat dalam pemerintahan dan oleh karena itu, pemilu merupakan tuntutan kedaulatan rakyat. Maka, pemilu merupakan suatu hal yang amat penting bahwa kehendak rakyat tidak dikecewakan dengan cara memastikan bahwa pemilu diselenggarakan secara langsung, umum, bebas, rahasia, jujur dan adil. Pemilu secara langsung merupakan sarana perwujudan kedaulatan rakyat guna menghasilkan pemerintahan negara yang demokratis berdasarkan Pancasila dan UUD 1945. Selain itu pemilu juga merupakan proses politik yang dinamis dan hanya bisa berjalan lancar dan tertib apabila dilaksanakan sesuai dengan peraturan perundang-undangan yang berlaku.

Sejalan dengan penguatan otonomi daerah, pemilihan terhadap kepala/wakil kepala daerah juga dipilih oleh rakyat daerah yang bersangkutan. Dalam Konstitusi Indonesia Pasal 18 ayat (4) dinyatakan "Gubernur, Bupati, dan Walikota masing-masing sebagai kepala pemerintah daerah provinsi, kabupaten, dan kota dipilih secara demokratis". Menurut Asshiddiqie (2002), perkataan 'dipilih secara demokratis' bersifat luwes, sehingga mencakup pengertian pemilihan kepala daerah langsung oleh rakyat ataupun oleh DPRD, seperti yang sekarang dipraktekkan di provinsi dan kabupaten/kota di Indonesia. Pengaturan tentang pemilihan kepala daerah/wakil kepala daerah pasca amandemen UUD 1945, hanya diatur dalam UndangUndang Nomor 22 Tahun 2007 tentang Penyelenggaraan Pemilu dan Undang-Undang Nomor 32 Tahun 2004 tentang Pemerintahan Daerah, maka secara normatif merupakan bagian dari kewenangan daerah untuk menyelenggarakannya. Kondisi ini telah menimbulkan tarik menarik antara pemerintah dengan pemerintah daerah, terutama dalam masalah pendanaan.

Pilkada langsung di Indonesia yang dimulai Juni 2005 sering dikatakan sebagai "lompatan demokrasi”. Istilah ini bisa diartikan secara positif maupun negatif. Dari sisi positif, pilkada langsung sebagai sarana demokrasi memberikan kesempatan kepada rakyat sebagai infrastruktur politik untuk memilih kepala daerahnya secara langsung melalui mekanisme pemungutan suara. Sarana ini akan membuat keseimbangan dengan suprastruktur politik, karena melalui pemilihan langsung rakyat dapat menentukan jalannya pemerintahan dengan memilih pemimpin yang dikehendaki secara bebas dan rahasia. Adapun dari sisi negatif, Pilkada langsung mencerminkan penafsiran sepihak atas manfaat dan proses pilkada. Proses ini sering dianggap sebagai "pesta demokrasi rakyat" di mana 
rakyat berhak untuk membuat apa saja, termasuk tindakan-tindakan anarki, baik atas inisiatif sendiri maupun yang dimobilisasi oleh kandidat dan pendukungnya atau karena dorongan partai politik sebagai pihak yang mengajukan kandidat tersebut. Bagi masyarakat umum, pilkada langsung sering juga ditafsirkan sebagai kesempatan bagi-bagi uang. Mereka tahu bahwa tiap-tiap kandidat menyediakan anggaran yang cukup besar untuk memenangkan kompetisi (Amirudin dan Bisri, 2006), maka tidaklah mengejutkan apabila kemudian muncul rasa tidak percaya rakyat akan pemilukada yang merupakan proses politik.

Dengan demikian, lembaga-lembaga yang terlibat dalam penyelenggaraan, termasuk pengawasan pemilukada sangat penting untuk melakukan penguatan peran mereka dengan baik. Hal ini berarti, lembaga-lembaga tersebut harus bekerja secara efisien, efektif, tidak memihak, adil, jujur, terbuka dan dapat dipercaya. Secara umum, persepsi rakyat mengenai proses pemilu yang berlangsung secara bersih, jujur, tertib, adil, dapat dipercaya, dan terbuka akan tercermin dari persepsi rakyat mengenai lembaga-lembaga serta pihak-pihak yang terlibat dalam penyelenggaraan pemilukada. Pengawasan menjadi salah satu komponen terpenting dalam penyelenggaraan, dan dapat menentukan berhasil atau tidaknya sebuah pemilu. Pengawasan pemilu adalah kegiatan mengamati, mengkaji, memeriksa dan menilai proses penyelenggaraan pemilu sesuai dengan peraturan yang telah ditetapkan.

Pemilukada langsung dibebani harapan besar bisa menjadi pintu masuk bagi perubahan lebih besar, menyangkut sistem politik yang lebih demokratis. Namun, tetap saja harapan perubahan itu dinilai masih belum sejalan dengan kecenderungan dalam sistem kepartaian Indonesia yang masih sentralistik, justru ketika demokrasi dan juga desentralisasi membutuhkan lembaga politik yang dapat menjamin transparansi dan akuntabilitas. Keberadaan Panwaslu sangatlah penting dalam mengawasi pelaksanaan penyelenggaraan pemilu agar sesuai dengan asas pemilu yang langsung, umum, bebas, rahasia, jujur dan adil. Panwaslu memiliki fungsi dan peran strategis dalam upaya untuk menciptakan penyelenggaraan pemilu yang demokratis.

Oleh karena itu, melalui kajian ini, penulis ingin mengidentifikasi peran Penwaslu dalam penyelenggaraan Pemilukada di Kabupaten Jembrana guna melihat langkah-langkah apa saja yang ditempuh oleh Panwas dalam mengatasi hambatan dan sekaligus meningkatkan peran Panwaslu dalam pemilukada, dengan tujuan agar diperoleh solusi penguatan peran Panwaslu ke depan. Pemilihan Kabupaten Jembrana sebagai lokasi kajian, didasarkan pada pertimbangan bahwa merupakan salah satu kabupaten yang menyelenggarakan pemilukada di tahun 2010, dengan dinamika yang cukup tinggi. Hal itu ditandai dengan jumlah pengaduan yang cukup banyak terhadap pelaksanaan Pemilukada.

\section{METODE PENELITIAN}

\section{Teknik Pendekatan}

Penelitian ini menggunakan pendekatan kualitatif yang bertujuan untuk mendapatkan sebuah deskripsi analitis terhadap peran Panwaslu dalam tahapan pelaksanaan pemilukada. Data-data yang diperoleh, baik data sekunder maupun data primer disusun dan dianalisis secara kualitatif sesuai dengan permasalahan yang telah dirumuskan. Teknik pengumpulan data berbentuk observasi terhadap obyek, utamanya hal-hal yang terkait dengan pengawasan pemilu dalam penyelenggaraan pemilukada di Kabupaten Jembrana. Konteks dari pengamatan terhadap proses Pemilukada, diharapkan dapat memahami secara lebih utuh terkait dengan masalah yang akan dianalisis lebih lanjut. Melalui observasi ini pula, diharapkan bahwa setiap unsur yang dapat diperoleh bersandar pada data-data atau informasi yang bersifat formal. Unsur "natural setting" menjadi kekuatan dari pengamatan yang dilakukan, dengan berusaha menangkap setiap makna dari proses penyelenggaraan pemilukada.

Hasil observasi akan diperdalam dengan melakukan indept interview. Wawancara mendalam (indept interview) terhadap informan dilakukan berdasarkan panduan wawancara yang telah dipersiapkan. Hasil yang didapat melalui kedua teknik pengumpulan data ini, kemudian dianalisis secara deskriptif. Informan diperoleh dengan teknik purposive, yaitu teknik penentuan sampel untuk tujuan tertentu saja (Sugiyono, 2005). Informan yang dipergunakan sebagai sumber data primer, yaitu: Panwas, KPUD Kabupaten Jembrana-Bali, DPRD, Kejaksaan, Kepolisian, LSM, dan tokoh masyarakat setempat.

\section{Konsep Pilkada Langsung}

Pemilihan umum menjadi salah satu indikator stabil dan dinamisnya sistem demokratisasi suatu bangsa. Dalam konteks Indonesia, penyelenggaraan pemilu memang secara periodik sudah berlangsung sejak awal kemerdekaan bangsa ini, akan tetapi proses demokratisasi lewat pemilupemilu yang terdahulu belum mampu menghasilkan nilai-nilai demokrasi yang matang akibat sistem politik yang otoriter. Harapan untuk menemukan format demokrasi yang ideal mulai nampak setelah penyelenggaraan Pemilu 2004 lalu yang berjalan relatif cukup lancar dan aman. Untuk ukuran bangsa yang baru beberapa tahun lepas dari sistem otoritarian, penyelenggaraan Pemilu 2004 yang terdiri dari pemilu legislatif dan pemilu presiden secara langsung yang berjalan tanpa tindakan kekerasan dan menjadi prestasi bersejarah bagi bangsa ini. 
Sejarah Pilkada di Indonesia juga merupakan sebuah bukti dari bentuk aktualisasi dan agregasi kepentingan masyarakat yang dilembagakan melalui berbagai proses dan instrumen demokrasi tersebut. Entitas masyarakat yang turut berafiliasi dengan kekuatan membentuk sebuah wadah kepentingan bersama untuk memenangkan berbagai pemilihan perwakilan politik. Didorong pula kepada sebuah perubahan warna dan dinamika akibat dari konstalasi politik di Indonesia yang memasuki trasnsisi demokrasi yang diawali dengan Reformasi 1998, telah membawa banyak perubahan politik di Indonesia. Perubahan yang mengisyaratkan, terbukanya ruang bagi masyarakat untuk melakukan dan mendapat perlindungan dari aktivitas politiknya. Hal yang secara nyata dapat kita lihat dari sebuah euforia kemenangan politik di Indonesia, yang menghasilkan sebuah sistem kepatutan politik yang baru. Sebuah gambaran fenomena politik Indonesia, yang diikuti perubahan bentuk basis politik di masyarakat (Koirudin, 2004). Kebebasan dalam menentukan warna politik dan hilangnya unsur pemaksaan terhadap hak politik masyarakat telah melahirkan instrumen penunjang keberlangsungan demokrasi perwakilan di Indonesia melalui partisipasi politik masyarakat.

Partisipasi politik masyarakat merupakan perangkat penting karena teori demokrasi yang menyebutkan bahwa perlunya partisipasi politik masyarakat pada dasarnya disebabkan bahwa masyarakat tersebutlah yang paling mengetahui apa yang mereka kehendaki (Budiarjo, 1982). Azas dasar dalam sebuah negara yang demokrasi, yakni kedaulatan rakyat menentukan jalannya pemerintahan. Perwujudan azas kedaulatan rakyat ini dalam kehidupan pemerintahan terbukti dengan dilibatkannya rakyat secara intensif dalam memutuskan berbagai kebijakan pemerintah. Ukuran kedaulatan rakyat dilihat dari semakin besarnya porsi peran yang dimainkan oleh rakyat, serta semakin selarasnya kepentingan rakyat dengan kebijakan yang dikeluarkan pemerintah.

Partisipasi politik sendiri adalah merupakan kegiatan seseorang atau kelompok orang untuk ikut serta aktif dalam kehidupan politik yaitu dengan jalan memilih pimpinan Negara dan masyarakat, dan secara langsung atau tidak langsung mempengaruhi kebijakan pemerintah (public policy), yakni kegiatan yang mencakup tindakan seperti pemberian suara dalam pemilihan umum, menghadiri rapat umum, menjadi anggota suatu partai politik dan kelompok kepentingan (Budiarjo, 1982).

Sebagai sebuah implementasi terhadap partisipasi politik masyarakat dalam bentuknya, maka lahirlah sistem pemilu. Dalam pengertiannya, pemilihan umum merupakan suatu kegiatan yang sering diidentikkan sebagai suatu ajang pesta demokrasi, yang merupakan sarana pelaksanaan kedaulatan rakyat untuk memilih Presiden/Wakil Presiden, anggota Dewan Perwakilan Rakyat,
Gubernur/Wakil Gubernur, Walikota/Wakil Walikota ataupun memilih Bupati/Wakil Bupati berdasarkan peraturan yang berlaku. Melalui pemilihan umum, maka hak asasi rakyat dapat tersalurkan, demikian juga halnya dengan hak untuk sama didepan hukum dan pemerintahan (Mahfud, 1999).

Dalam penentuan dan penetapan perwakilan di lembaga eksekutif ketatanegaraan, maka lahirlah sebuah sistem yang turut mengimplementasikan partisipasi masyarakat secara langsung dalam menentukan arah kebijakan politik pemerintah. Sebuah sistem partisipasi langsung dalam menentukan kepemimpinan daerah melalui proses Pemilihan Kepala Daerah (Pilkada). Dikatakan demikian, karena dalam prosesnya masyarakat memiliki hak dipilih sebagai pemimpin atau wakil rakyat, maupun memilih pemimpin daerah secara langsung. Hal ini berlaku sejak diberlakukannya Undang-Undang 32 Tahun 2004 tentang Pemerintahan Daerah yang didalamnya mengatur pilkada secara langsung. Maka mulai pertengahan 2005, satu persatu provinsi dan kabupaten/kota yang masa bakti kepala daerahnya sudah berakhir, melaksanakan pilkada yang melibatkan masyarakat secara langsung. Pemilihan kepala daerah/wakil kepala daerah secara langsung diatur dalam pasal 56 jo pasal 119 Undang-Undang Nomor 32 Tahun 2004 (Prihatmoko, 2005) dan PP Nomor 6 Tahun 2005 tentang Tata Cara Pemilihan, Pengesahan, Pengangkatan dan Pemberhentian Kepala Daerah.

Dengan lahirnya Undang-Undang Nomor 32 Tahun 2004 sebagai pengganti Undang-Undang Nomor 22 Tahun 1999, yang merupakan landasan hukum bagi pelaksanaan pilkada langsung, rakyat memiliki kedaulatan penuh atas hak politiknya dalam memilih pemimpin mereka. Semangat pilkada langsung adalah memberikan ruang yang luas bagi partisipasi politik masyarakat untuk menentukan kepala daerah sesuai dengan aspirasi dan kebutuhan di daerah masing-masing, sehingga diharapkan kebijakan-kebijakan dari pemerintah nantinya sesuai dengan harapan dan keinginan rakyat pada umumnya (Edwin, 2005)

Sejak bergulirnya pilkada, maka lembaran baru demokrasi di Indonesia dimulai. Pilkada pertama kali dilaksanakan pada bulan Juni 2005, yakni sejak berlakunya Undang-Undang Nomor 22 Tahun 2007 tentang Penyelenggara Pemilihan Umum, pilkada dimasukkan dalam rezim pemilu, sehingga secara resmi bernama Pemilihan Umum Kepala Daerah/Wakil Kepala Daerah berdasarkan Undang- Undang Nomor 32 Tahun 2004. Peserta Pilkada adalah pasangan calon yang diusulkan secara berpasangan oleh partai politik atau gabungan partai politik, kecuali di Nanggroe Aceh Darussalam, di mana peserta pilkada dapat berasal dari calon independen dan partai politik lokal.

Adanya ketentuan peserta Pilkada hanya dapat ditentukan ataupun dicalonkan oleh partai 
politik dan gabungan partai politik, hal ini akan menutup hak konstitusional calon perseorangan (independen) dalam pilkada. Setelah mengadakan uji materiil, pada tanggal 23 Juni 2007, Mahkamah Konstitusi (MK) melalui putusan Nomor 5/PUUV/2007 yang menggugurkan Pasal 56, 59, dan 60 Undang-Undang Nomor 32 Tahun 2004 memuluskan calon independen maju dalam pilkada, yang sebelumnya hanya memberi kesempatan kepada partai politik atau gabungan partai politik dan menutup hak konstitusional calon perseorangan (independen) dalam Pilkada, bertentangan dengan UUD 1945. Suatu negara dapat dikatakan demokratis bila memenuhi prasyarat antara lain memiliki kebebasan kepada masyarakat untuk merumuskan prefensi-prefensi politik mereka melalui jalur-jalur perserikatan, informasi dan komunikasi, memberikan ruang berkompetisi untuk jabatan politik.

Pilkada langsung merupakan salah satu kemajuan terbesar dalam reformasi politik di Indonesia (Edwin, 2005). Rakyat dapat menentukan presiden, gubernur dan bupati atau walikota melalui pemilihan langsung. Yang perlu digaris bawahi, walaupun untuk tahap awal semua berlaku terlebih dahulu harus melewati saringan partai politik, akan tetapi jalur calon independen juga kemudian dibuka. Artinya, sebelum rakyat memilih, terlebih dahulu pilihan itu ditentukan partai politik itu adalah konsep lama.

Sesuai ketentuan Undang-Undang Nomor 32 Tahun 2004 pasal 56, setiap kontestan pilkada diwajibkan memakai kendaraan berupa partai politik dan gabungan parpol. Kendaraan ini tidak hanya berfungsi sebagai alat untuk masuk arena, melainkan juga sebagai mesin yang bekerja untuk mengumpulkan dukungan rakyat. Calon yang belum dikenal publik, mereka harus berusaha keras mendekati publik, memperkenalkan diri, visi misi, program aksi ke publik. Usaha keras ini membutuhkan dukungan kekuatan mesin politik. dalam mengambil hati rakyat juga diperlukan dalam meraih kekuasaan.

Pilkada langsung merupakan fenomena baru bagi politik Indonesia, jika fenomena ini mampu dikelola dengan baik, maka penguatan demokrasi akan terjadi di berbagai tingkatan dari daerah bahkan nasional, seperti yang dikemukakan Tip O’ Neil “all politics is local" yang memiliki makna bahwa suatu kehidupan demokrasi di tingkat nasional akan tumbuh dengan baik dengan mapan dan dewasa jika di tingkat lokal nilai-nilai ini telah mengakar terlebih dahulu (Agustino, 2005). Pilkada yang diagendakan berlangsung mulai Juni 2005 dapat dikatakan sebagai langkah awal untuk mewujudkan perbaikan demokrasi di Indonesia yang berada di tingkat daerah dan dianggap sebagai tahap pencapaian kemajuan dalam perkembangan demokrasi negara ini, di mana dalam ilmu politik disepakati bahwa kualitas demokrasi turut pula ditentukan oleh berkualitas atau tidak proses rekrutmen wakil rakyat yang mendapat mandat untuk memimpin pemerintahan.

Demokratisasi lokal adalah implikasi dari desentralisasi yang dijalankan di daerah-daerah sebagai perwujudan dari proses demokrasi di Indonesia. Konsepnya mengandaikan pemerintahan itu dari, oleh dan untuk rakyat. Hal paling mendasar dalam demokrasi adalah keikutsertaan rakyat, serta kesepakatan bersama atau konsensus untuk mencapai tujuan yang dirumuskan bersama. Perkembangan desentralisasi menuntut adanya proses demokrasi bukan hanya di tingkat regional tetapi di tingkat lokal. Dalam pilkada langsung diharapkan dapat menguatkan demokratisasi di tingkat lokal, khususnya yang berkaitan dengan pembangunan legitimasi politik, sebab asumsinya kepala daerah terpilih akan memiliki mandat dan legitimasi yang kuat sebab didukung oleh suara pemilih nyata (real voters) yang merefleksikan konfigurasi kekuatan politik dan kepentingan dari konstituen. Dengan demikian maka dapat dipastikan bahwa kepala daerah yang terpilih secara demokratis mendapatkan dukungan dari sebagian besar warga daerah tersebut.

Selanjutnya dengan pemilihan kepala daerah langsung diharapkan mampu membangun local accountabilty, di mana ketika seorang kandidat terpilih menjadi kepala daerah, maka para wakil rakyat yang mendapat mandat akan meningkatkan kualitas akuntabilitasnya. Melihat fenomena sebelumnya local accountabilty sangat kurang sebab mekanisme pemilihan Kepala Daerah yang lama cenderung menciptakan ketergantungan yang berlebih dari kepala daerah terhadap DPRD. Sehingga akuntabilitasnya cenderung mengarah pada anggota Dewan, dibanding rakyat yang seharusnya dilayani. Maka, terkadang muncul fenomena politik uang antara kepala daerah dan anggota dewan untuk meloloskan Laporan Pertanggungjawaban (LPJ), hal ini dapat terjadi mengingat dalam pemilihan kepala daerah langsung ini terdapat perubahan dalam arena permainan, menurut Agustino (2005) arena permainan sekarang telah berubah dari "politik dalam ruangan" menjadi "politik luar ruangan" yang kini semakin berkembang. Pemasaran politik (political marketing) menjadi lebih penting, berbeda dengan cara-cara yang ditempuh dimasa lalu seperti negoisasi elite dengan lobi, meskipun cara ini masih tetap dapat dilakukan. Akhirnya penguatan yang terjadi di dalam local accountabilty jika berhasil diwujukan maka kondisi check and balances antar lembaga negara dapat mengarah pada pemberdayaan masyarakat dan penguatan demokrasi di tingkat lokal.

Dengan adanya pemilihan kepala daerah langsung ini maka akan ikut meningkatkan kualitas kesadaran politik masyarakat dimana di dalamnya terdapat pula kualitas partisipasi rakyat sebab rakyat dengan kesadarannya akan dihadapkan pada penggunaan hak pilih untuk ikut menentukan siapakah pemimpin yang layak untuk daerahnya, 
tentu saja dalam hal ini dibutuhkan pertimbangan kearifan, kecerdasan bahkan moralitas untuk peduli terhadap perkembangan dan kemajuan daerahnya serta kemakmuran dan kesejahteraan rakyat di daerahnya.

\section{Peran Panitia Pengawas Pemilu (Panwaslu) dalam Pemilukada}

Pengawasan menjadi salah satu komponen penting dalam menentukan berhasil atau tidaknya sebuah pemilihan umum (pemilu). Badan Pengawas Pemilu (Bawaslu) dan Panitia Pengawas Pemilihan (Panwaslu) memiliki peran penting untuk menjaga agar pemilu dilaksanakan sesuai asas pemilu yang langsung, umum, bebas, rahasia, jujur, dan adil sesuai dengan peraturan perundang-undangan yang berlaku.

Dalam konteks pemilu di Indonesia, terkait dengan electoral process, hal penting adalah tentang pengawasan terhadap penyelenggaraan pemilu. Dalam konteks ini, penyelenggaraan pemilu yang bebas dan adil, dan kelembagaan yang dibutuhkan pada konteks dimaksud adalah terkait dengan: (1) Kemandirian dan ketidakberpihakan; (2) Efisiensi; (3) Profesionalisme; (4) Penangan yang cepat terhadap pertikaian yang ada; (5) Stabil; dan (6) Transparansi (IDEA, 2000). Upaya mewujudkan pemilu yang jujur, adil, juga untuk menghindari terjadinya delegitimasi pemilu, masalah-masalah penegakkan hukum pemilu yang harus diselesaikan secara komfrehensif. Panwaslu memiliki fungsi dan peran strategis dalam upaya menciptakan penyelenggaraan pemilu yang demokratis, di mana kewenangan ini sudah diatur dalam Undang-Undang Nomor 22 Tahun 2007 pasal 76, 78, 80, 82 dan 84 .

Sebelum diundangkannya Undang-Undang Nomor 22 Tahun 2007, secara kelembagaan keberadaan pengawas pemilu bersifat ad hoc. Berbeda dengan KPU yang sejak pemilu tahun 2004 telah permanen keberadaannya. Secara kelembagaan akan sangat berbeda gaya dan managerialnya dengan lembaga yang ad hoc. Dengan diundangkannya Undang-Undang Nomor 22 Tahun 2007, maka Panwaslu Pusat disebut sebagai Badan Pengawas Pemilu (Bawaslu) telah dipermanenkan/tetap melalui Pasal 70 ayat (2).

Sebagai sebuah badan yang baru dan permanen, tentunya masih banyak hal yang harus ditata dan dikelola ke depan mulai kelembagaan, keanggotaan, administratif serta hubungan dengan lembaga lain yang terkait. Dalam kondisi demikian, tentu para pihak harus memakfumkan jika dalam perjalanannya masih ada hal-hal yang belum bisa optimal, lebih-lebih menyangkut kewenangan dan pendanaan. Jika Bawaslu telah ditempatkan sebagai lembaga yang permanen, bagaimana dengan jajaran dibawahnya. Undang-Undang Nomor 22 Tahun 2007 mengamanatkan, keberadaan Panwaslu provinsi dan Panwaslu kabupaten dan kota bersifat ad hoc. Sifat ad hoc ini, dalam pelaksanaan tugas dan kewenangannya menimbulkan problematik yang komplek. Jika diurai, maka akan ditemukan deretan permasalahan yang melilit di dalamnya, mulai kelembagaan, anggaran, personil dan juga kesekretariatan serta tugas dan kewenangan yang diberikan oleh undang-undang.

Berbeda dengan seluruh Komisi Pemilihan Umum (KPU) baik provinsi dan kabupaten/kota yang bersifat permanen/tetap dan memiliki hubungan yang hirarkis antara KPU, KPU Provinsi, dan KPU Kabupaten/Kota (Pasal 5 ayat (1) dan (2) UndangUndang Nomor 22 Tahun 2007), Panwaslu provinsi dan kabupaten/kota dengan Bawaslu tidak sebagai organisasi yang memiliki herarki, selain hanya bersifat ad hoc. Kondisi yang demikian akan membawa implikasi yang luas dalam pelaksanaan tugas dan kewenangan yang diamanatkan oleh undang-undang.

Dengan demikian, dalam tinjauan normatif, keberadaan KPU dan Bawaslu beserta jajaran di bawahnya memiliki kedudukan yang sama dan sederajat yang dilahirkan secara bersama-sama oleh induk yang sama. Untuk memperkuat kapasitas dan kelangsungan dalam membangun tanggungjawab serta pelaksanaan pengawasan terhadap penyelenggara dalam penyelenggaraan pemilukada, kedudukan Panwaslu provinsi dan kabupaten/kota selayaknya ditingkatkan sebagai lembaga yang permanen sebagaimana KPU provinsi dan kabupaten/kota, di mana anggota Panwaslu yang hanya 3 (tiga) orang, lebih sedikit dibandingkan dengan anggota KPU provinsi dan kabupaten/kota yang berjumlah lima orang.

Keberadaan Panwaslu sangatlah penting dalam mengawasi pelaksanaan penyelenggaraan pemilu agar sesuai dengan peraturan perundangundangan. Secara normatif, tugas dan wewenang Panwaslu yang telah diatur dalam Undang-Undang Nomor 22 Tahun 2007, bahkan diperkuat dengan disahkannya Undang-Undang Nomor 10 Tahun 2008 tentang Pemilu Anggota DPR, DPD dan DPRD, di mana lebih memperjelas fungsi pengawasan yang harus dilaksanakan oleh Bawaslu, Panwaslu provinsi, Panwaslu kabupaten/kota. Pengawasan ini dimulai dari tahapan pelaksanaan verifikasi Partai Politik Calon Peserta Pemilu (Pasal 18, Undang-Undang Nomor 10 Tahun 2008). Pengawasan dimaksud agar dalam verifikasi yang dilakukan oleh KPU, KPU provinsi dan KPU kabupaten/kota tidak merugikan dan/atau menguntungkan partai politik calon peserta Pemilu.

Secara garis besar, tugas-tugas pengawasan lain yang wajib dilakukan. yaitu mengawasi tahapan penyelenggara pemilu, meliputi; pemutakhiran data pemilih berdasarkan data kependudukan, penetapan daftar pemilih sementara, daftar pemilih tetap, pencalonan yang berkaitan dengan persyaratan dan tata cara pencalonan anggota DPRD, proses penetapan calon anggota DPD, DPRD, pelaksanaan kampanye, perlengkapan pemilu dan pendistri- 
busiannya, pelaksanaan penghitungan dan pemungutan suara hasil pemilu, pengawasan seluruh proses penghitungan suara, proses rekapitulasi penghitungan suara, pelaksanaan penghitungan dan pemungutan suara ulang, pemilu lanjutan, pemilu susulan, proses penetapan hasil pemilu anggota DPRD, mengawasi sosialisasi penyelenggaraan pemilu, dan sebagainya.

Adapun tugas Panwaslu kabupaten/kota yang berjumlah 3 (tiga) orang sebagaimana diatur dalam Pasal 78 ayat (1), adalah mengawasi tahapan penyelenggaraan Pemilu di wilayah kabupaten/kota yang meliputi: pemutakhiran data pemilih berdasarkan data kependudukan dan penetapan daftar pemilih sementara dan daftar pemilih tetap; pencalonan yang berkaitan dengan persyaratan dan tata cara pencalonan anggota DPRD kabupaten/kota dan pencalonan kepala daerah dan wakil kepala daerah kabupaten/kota; proses penetapan calon anggota DPRD kabupaten/kota dan pasangan calon kepala daerah dan wakil kepala daerah kabupaten/ kota; penetapan pasangan calon kepala daerah dan wakil kepala daerah kabupaten/kota; pelaksanaan kampanye; perlengkapan Pemilu dan pendistribusiannya; pelaksanaan pemungutan suara dan penghitungan suara hasil Pemilu; mengendalikan pengawasan seluruh proses penghitungan suara; pergerakan surat suara dari tingkat TPS sampai ke PPK; proses rekapitulasi suara yang dilakukan oleh KPU kabupaten/kota dari seluruh kecamatan; pelaksanaan penghitungan dan pemungutan suara ulang, Pemilu lanjutan, dan Pemilu susulan; dan proses penetapan hasil Pemilu anggota DPRD kabupaten/kota dan Pemilu kepala/wakil kepala daerah kabupaten/kota.

Tugas lainnya, adalah menerima laporan dugaan pelanggaran terhadap pelaksanaan peraturan perundang-undangan mengenai Pemilu; menyelesaikan temuan dan laporan sengketa penyelenggaraan Pemilu yang tidak mengandung unsur tindak pidana; menyampaikan temuan dan laporan kepada KPU kabupaten/kota untuk ditindaklanjuti; meneruskan temuan dan laporan yang bukan menjadi kewenangannya kepada instansi yang berwenang; menyampaikan laporan kepada Bawaslu sebagai dasar untuk mengeluarkan rekomendasi Bawaslu yang berkaitan dengan adanya dugaan tindakan yang mengakibatkan terganggunya tahapan penyelenggaraan Pemilu oleh penyelenggara Pemilu di tingkat kabupaten/kota; mengawasi pelaksanaan tindak lanjut rekomendasi Bawaslu tentang pengenaan sanksi kepada anggota KPU kabupaten/kota, sekretaris dan pegawai sekretariat KPU kabupaten/ kota yang terbukti melakukan tindakan yang mengakibatkan terganggunya tahapan penyelenggaraan Pemilu yang sedang berlangsung; mengawasi pelaksanaan sosialisasi penyelenggaraan Pemilu; dan melaksanakan tugas dan wewenang lain yang diberikan oleh undang-undang.
Dalam pelaksanaan tugas sebagaimana dimaksud pada ayat (1), Panwaslu kabupaten/kota berwenang untuk memberikan rekomendasi kepada KPU untuk menonaktifkan sementara dan/atau mengenakan sanksi administratif atas pelanggaran sebagaimana dimaksud pada ayat (1) huruf g; memberikan rekomendasi kepada yang berwenang atas temuan dan laporan terhadap tindakan yang mengandung unsur tindak pidana Pemilu. Adapun Pasal 79 mengatur bahwa Panwaslu kabupaten/kota berkewajiban bersikap tidak diskriminatif dalam menjalankan tugas dan wewenangnya; melakukan pembinaan dan pengawasan terhadap pelaksanaan tugas Panwaslu pada tingkatan di bawahnya; menerima dan menindaklanjuti laporan yang berkaitan dengan dugaan adanya pelanggaran terhadap pelaksanaan peraturan perundang-undangan mengenai Pemilu; menyampaikan laporan hasil pengawasan kepada Panwaslu provinsi sesuai dengan tahapan Pemilu secara periodik dan/atau berdasarkan kebutuhan; menyampaikan temuan dan laporan kepada Panwaslu provinsi berkaitan dengan adanya dugaan pelanggaran yang dilakukan oleh KPU kabupaten/kota yang mengakibatkan terganggunya penyelenggaraan tahapan Pemilu di tingkat kabupaten/kota; dan melaksanakan kewajiban lain yang diberikan oleh peraturan perundang-undangan.

Secara teoritis, tugas dan wewenang Panwaslu yang telah diatur dalam Undang-Undang Nomor 22 Tahun 2007, diperkuat oleh UndangUndang Nomor 10 Tahun 2008 yang lebih memperjelas fungsi pengawasan yang harus dilaksanakan oleh Bawaslu, Panwaslu provinsi, Panwaslu kabupaten/kota. Pemutakhiran Data dan Penetapan Daftar Pemilih juga memerlukan pengawasan sebagaimana diatur pada Pasal 48 dalam Undang-Undang yang sama, menyebutkan Bawaslu, Panwaslu provinsi, Panwaslu kabupaten/kota, Panwaslu kecamatan dan Pengawas Pemilu lapangan melakukan pengawasan atas pelaksanaan pemutakhiran data pemilih, penyusunan dan pengumuman Daftar Pemilih Sementara (DPS), perbaikan dan pengumuman DPS hasil perbaikan, penetapan dan pengumuman Daftar Pemilih Tetap (DPT), daftar pemilih tambahan dan rekapitulasi DPT yang dilaksanakan oleh KPU, KPU propinsi, KPU kabupaten/kota, PPK dan PPS.

Karena luasnya cakupan pengawasan tahapan kampanye Pemilu yang harus dilakukan, maka pengawasan Pemilu harus memilih fokus pengawasan yang akan dilakukan. Fokus pengawasan dipilih antara lain berdasarkan tingkatan dan wilayah pengawasan masing-masing pengawas pemilu, metode kampanye yang dilakukan peserta pemilu, materi kampanye, dana kampanye, serta titik-titik rawan yang mungkin terjadi pada pelaksanaan kampanye.

Dalam melaksanakan tugas Panwaslu berwenang untuk memberikan rekomendasi kepada yang berwenang atas temuan dan laporan terhadap 
Tabel 1. Nama dan Nomor Urut Pasangan Calon Bupati/Wakil Bupati Jembrana Peserta Pemilukada Tahun 2010

\begin{tabular}{cll}
\hline $\begin{array}{c}\text { No. } \\
\text { Urut }\end{array}$ & \multicolumn{1}{c}{ Nama Pasangan Calon } & \multicolumn{1}{c}{ Partai Pengusung } \\
\hline 1. & I Wayan Dendra dan Ketut Sumantra & Partai PNBK Indonesia, PIB, PKB dan Hanura \\
2. & I Putu Artha dan Made Kembang Hartawan & $\begin{array}{l}\text { Partai PDI-Perjuangan } \\
\text { Partai Demokrat \& Golkar }\end{array}$ \\
I Gede Ngurah Patriana Krisna dan Ketut & Pabanda & Partai Gerindra, PPP, PKPB, PKS, PAN, PDP, PIS, PKPI, \\
4. & $\begin{array}{l}\text { I Gede Made Kartikajaya Dan } \\
\text { I Gusti Ngurah Cipta Negara }\end{array}$ & PKNU, PDS, PPPI dan PKP \\
\hline
\end{tabular}

tindakan yang mengandung unsur pidana Pemilu. Panwaslu memiliki kewajiban diantaranya untuk tidak bersikap deskriminatif dalam menjalankan tugas dan wewenangnya, sebagaimana diatur pada Pasal 78 Undang-Undang Nomor 22 Tahun 2007, melakukan pembinaan dan pengawasan pemilu pada tingkatan dibawahnya, menerima dan menindaklanjuti laporan yang berkaitan dengan dugaan adanya pelanggaran peraturan perundang-undangan mengenai pemilu.

\section{HASIL DAN PEMBAHASAN}

\section{Pilkada Kabupaten Jembrana}

Pelaksanaan Pemilukada di Kabupaten Jembrana telah ditetapkan 27 Desember 2010, sesuai dengan peraturan perundangan yang terdapat dalam Undang-Undang No 32 tahun 2004 dan UndangUndang No 12 tahun 2008. Atas penetapan itu, KPUD Jembrana pun telah menentukan tahapan pilkada. Bupati Jembrana, Provinsi Bali, I Gde Winasa akan mengakhiri jabatannya pada tanggal 15 Nopember 2010. Berarti Pemilihan Kepala Daerah (Pilkada) di kabupaten tersebut harus dilakukan tujuh bulan sebelum masa jabatan itu berakhir. Akibatnya, akan ada penetapan pelaksana tugas (plt) Bupati Jembrana, sebab, masa bakti jabatan kedua Prof. Gede Winasa berakhir bulan November 2010.

Berdasarkan proses seleksi administrasi dan persyaratan yang ditetapkan, maka KPU Kabupaten Jembrana menetapkan 4 (empat) pasang calon Bupati/Wakil Bupati Jembrana tahun 2010.

Tabel 2. DPT Pemilukada Kabupaten Jembrana Tahun 2010

\begin{tabular}{clc}
\hline No. & Kecamatan & Jumlah \\
\hline 1. & Melaya & 41.569 \\
2. & Negara & 59.962. \\
3. & Jembrana & 42.761 \\
4. & Mendoyo & 48.470 \\
5. & Pekutatan & 21.788 \\
\hline
\end{tabular}

Sumber: KPU Kabupaten Jembrana, 2010.

Dalam DPT ditingkat KPU Kabupaten Jembrana pada Pemilukada 2010, jumlah pemilih yang berhak memilih saat pencoblosan 27 Desember 2010 berjumlah 214.550, yang terdiri dari jumlah pemilih laki-laki 105.130 dan perempuan berjumlah 109.420, tersebar di 447 TPS dan 1 TPS tambahan, yakni LP (lembaga Permasyarakatan). Adapun rekapitulasi DPT Pemilukada Kabupaten Jembrana tahun 2010 dapat dilihat pada Tabel 2.

\section{Peran Panwaslu Dalam Pemilukada Kabupaten Jembrana Jembrana}

Pemilukada merupakan salah satu kegiatan penting sebagai implementasi nilai-nilai demokrasi sekaligus mencerminkan puncak dinamika demokrasi daerah. Dalam konteks budaya Bali, nilainilai kearifan lokal tri hita karana dan manyama braya yang pada hakekatnya selaras dengan nilainilai luhur Pancasila, sangat relevan diimplementasikan dalam mendorong pembangunan di Kabupaten Jembrana. Terlebih lagi dalam mendukung suksesnya pelaksanaan Pemilukada yang direncanakan pada tanggal 27 Desember 2010.

Panwaslu Pemilukada Jembrana dibentuk Pasca Putusan MK Nomor 11/PUU-VIII/2010, Bawaslu menegaskan pasca putusan Mahkamah Konstitusi (MK) menyerahkan proses pembentukan dan pelantikan Panwaslu di tangan Bawaslu. Proses pembentukan Panwaslu selama ini sangat lambat dan bernuansa "politisasi rekrutmen", saat ini berjalan jauh lebih cepat, terarah, dan bisa mengarahkan pada kualifikasi dari hasil-hasilnya. Bila sebelumnya pembentukan 193 Panwas dibutuhkan waktu empat bulan maka sejak putusan MK, Bawaslu dapat melantik anggota Panwaslu di 40 daerah dalam waktu satu bulan. Selain itu, proses pembentukan Panwaslu, tidak memakan ongkos sosial seperti sebelum adanya putusan MK tersebut. Dengan adanya Putusan MK tersebut maka Bawaslu mampu mengatasi persoalan selama ini membelenggu Bawaslu.

Bawaslu menilai, putusan MK Nomor 11/PUU-VIII/2010 merupakan terobosan hukum terbesar dalam sistem ketatanegaraan Indonesia, karena menghilangkan belenggu ketidakmandirian dari proses rekrutmen dan seleksi Panwaslukada provinsi serta kabupaten/kota dan kecamatan. Sebelum adanya putusan itu, Bawaslu sangat tergantung dari usulan nama calon Panwaslukada yang diusulkan oleh KPU provinsi dan kabupaten/kota. Dalam putusan MK, kedudukan 
Panwaslu semakin tegas dijabarkan berasal dari ketentuan diatur di dalam Pasal 22E UUD 1945. MK berpendapat fungsi penyelenggara pemilu tidak hanya dilaksanakan oleh KPU akan tetapi termasuk juga lembaga pengawas pemilu dalam hal ini Bawaslu sebagai satu kesatuan fungsi penyelenggaraan pemilu yang bersifat nasional, tetap dan mandiri.

Dalam pendapat hukumnya, MK berpandangan pentingnya keberadaan Bawaslu sebagai lembaga bersifat tetap. Tujuan dari Bawaslu bersifat tetap untuk mengawal terwujudnya pemilu langsung, umum, bebas, rahasia, jujur dan adil serta untuk memastikan integritas, profesionalitas, dan akuntabilitas KPU. Bawaslu juga memiliki fungsi check and balances ditujukan pada tindakan dan sikap KPU beserta jajarannya dalam menyelenggarakan pemilu merugikan hak konstitusional peserta pemilu yakni partai politik, calon anggota DPR, DPD dan DPRD, pasangan calon presiden dan wakil presiden serta pasangan calon kepala daerah dan wakil kepala daerah.

Pada pelaksanaan Pemilukada Kabupaten Jembrana tahun 2010, ada beberapa jenis pelanggaran yang terjadi di lapangan seperti terlibat dari tabel berikut.

Tabel 3. Jenis Pelanggaran Pemilukada Jembrana Tahun 2010

\begin{tabular}{clc}
\hline No. & \multicolumn{1}{c}{ Jenis Pelanggaran } & $\begin{array}{c}\text { Jumlah } \\
\text { Kasus }\end{array}$ \\
\hline 1. & $\begin{array}{l}\text { Kampanye terselubung (mencuri } \\
\text { start) }\end{array}$ & 3 \\
2. & Kampanye hitam (black campaign) & 2 \\
3. & Iklan di media massa dan televisi & 1 \\
& lokal & 1 \\
4. & DPS fiktif & 1 \\
5. & KPPS yang menjabat pengurus & \\
& Parpol & 1 \\
\hline
\end{tabular}

Sumber: Panwaslu Kabupaten Jembrana, 2010.

Dari tabel tersebut, terlihat bahwa kasus pelanggaran yang paling banyak terjadi adalah kampanye terselubung yang dilakukan para calon, yakni sebanyak 3 kasus yang dilaporkan oleh masyarakat. Selanjutnya, kampanye hitam (black campaign) menempati urutan berikutnya, yakni 2 kasus. Sedangkan kasus DPS fiktif, iklan di media massa, adanya KPPS yang merangkap sebagai pengurus Parpol dan DPT bermasalah masingmasing 1 kasus.

Meskipun Panwaslu Kabupaten Jembrana telah berupaya menyelesaikan permasalahan di atas, namun peranannya tidak dianggap penting oleh masyarakat setempat, karena Panwaslu Jembrana dianggap melempem, atau tidak menggigit, khususnya dalam menindaki pelanggaranpelanggaran yang terjadi, misalnya menindak langsung atas pemasangan-pemasangan baliho yang bukan pada tempat yang telah ditentukan, adanya pasangan yang telah melakukan kampanye dan sosialisasi-sosialisasi tersembunyi, sehingga masyarakat setempat menilai bahwa peran Panwaslu Kabupaten Jembrana ini tidak produktif, tidak dapat bekerja secara maksimal dalam menjalankan tugas dan fungsinya dalam melakukan pengawasan pelaksanaan Pemilu kepala daerah, dalam mengawasi beberapa tahapan Pemilu kepala daerah seperti pemutahiran data pemilih, pendaftaran pasangan calon. Permasalahan juga teridentifikasi ditingkat Pengawas Pemilu Lapangan (PPL), yang tidak dapat menjalankan tugas pengawasan secara optimal sesuai dengan peraturan perundangan yang berlaku.

Belum optimalnya tugas pengawasan oleh Panwaslu Kabupaten Jembrana, kesalahannya tidak dapat semata-mata dilemparkan begitu saja ke lembaga itu. Tidak sedikit kasus pelanggaran pemilu yang berhasil ditangani dengan meneruskan ke lembaga yang berwenang. Hanya saja, memang belum sebanding dengan banyaknya pelanggaran yang terjadi. Untuk itulah, peran serta dan kerjasama masyarakat luas pada umumnya, partai politik, pemerintah, LSM, pemantau dan juga penegak hukum (sentra gakumdu) diharapkan dapat memberikan sumbangsihnya sesuai dengan peran, tugas dan kewenangannya masing-masing, sehingga kualitas partisipasi masyarakat semakin baik dan kondusif dalam pengawasan pelaksanaan setiap tahapan pemilu.

Jadi, Panwaslu akan lebih seperti pintu gerbang dalam proses penyelesaian pelanggaran Pemilu. Maksudnya, diperlukan bantuan masyarakat dan pihak-pihak yang terkait untuk ikut aktif melaporkan pelanggaran-pelanggaran Pemilu yang terjadi. Panwaslu kemudian yang akan memutuskan sendiri atau menyerahkannya kepada instansi yang lebih berwenang untuk ditindaklanjuti sesuai dengan prosedur dan perundang-undangan yang berlaku.

\section{Faktor-faktor yang Mempengaruhi Kinerja Panwaslu dalam Pemilukada Kabupaten Jembrana}

Salah satu unsur penting yang menentukan keberhasilan penyelenggaraan pemilu adalah kinerja Panwaslu yang baik. Sayangnya, dalam beberapa hal peraturan yang sudah ada justru menghambat kinerja Panwaslu. Panwaslu, dari sisi yuridis normatif maupun sosiologis, berpotensi menjadi tidak efektif. Kondisi demikian berawal dari tumpang tindihnya ketentuan Undang-Undang Pemilu, serta adanya sejumlah faktor yang dapat mempengaruhi kinerja panwas dalam melaksanakan tugas dan wewenangnya dalam pelaksanaan pemilukada. Faktor-faktor tersebut, antara lain:

Pertama, Ketidaksiapan Anggaran. Kendala ini menjadi persoalan yang sangat umum dan menonjol dalam Pemilukada yakni ketidakpastian anggaran, keterlambatan persetujuan anggaran, pencairan yang tidak tepat waktu dan jumlah 
anggaran yang terbatas. Banyak dampak yang dirasakan oleh Panwaslu Jembrana terkait problem anggaran tersebut di antaranya; (1) Keterlambatan pembentukan panwascam dan PPL yang berarti menghambat pengawasan maksimal di kecamatan dan desa padahal peran PPL dan Panwascam sangat penting untuk pengawasan tahapan awal yakni pemutakhiran dan penetapan data pemilih, (2) Tidak maksimalnya pengawasan karena kurangnya dukungan operasional untuk menjalankan rencana pengawasan, dan lain-lain.

Kedua, Keterbatasan personil. Dengan jumlah personil yang minim ini sangat menghambat kinerja Panwaslu. Pasca berlakunya Undang-Undang Nomor 22 Tahun 2007, jumlah Bawaslu dan Panwaslu semakin sedikti. Bawaslu berjumlah 5 orang dan Panwaslu di daerah berjumlah 3 orang. Kondisi ini sungguh memberatkan, khususnya di level daerah. Dengan jumlah 5 orang saja, panwaslu daerah merasa cukup berat menjalankan tugas yang sesungguhnya memang berat, apalagi hanya dengan jumlah 3 orang. Sebaiknya untuk personil mempunyai latar belakang hukum karena panwaslu lembaga yang berhubugan dengan hukum.

Ketiga, Terbatasnya kewenangan yang dimiliki Panwaslu untuk menindaklanjuti dugaan pelanggaran Pemilu Kada. Berdasarkan UndangUndang 22/2007, disebutkan bahwa kewenangan lembaga Panwas Pemilu "sekedar" menyampaikan temuan dan laporan dugaan pelanggaran administrasi Pemilu kepada KPU untuk ditindaklanjuti, serta meneruskan temuan dan laporan tentang adanya dugaan pelanggaran tindak pidana Pemilu kepada Kepolisian. Kelemahan Panwaslu selama ini terletak pada ketidakmampuan menindaklanjuti pelanggaran yang dilaporkan masyarakat. Kondisi ini disebabkan oleh Panwaslu masih tersandera pada posisi pemihakan untuk salah satu pasangan calon atau partai politik. Tak heran muncul kesan Panwaslu macan ompong lantaran kinerjanya lemah pada pemilu legislatif. Kecilnya peran Panwas itu diibaratkan seperti semut yang akan berhadapan dengan gajah-gajah calon presiden dalam kampanye pemilihan presiden (pilpres).

Keempat, Fasilitas sarana dan prasarana yang kurang memadai. Sarana dan prasarana yang tidak maksimal membuat Panwaslu jembrana tidak dapat kita bisa maksimal bekerja sesuai dengan target dan tupoksi yang ada, misalnya tempat untuk melakukan kegiatan karena selama ini kantor Panwaslu menempati bangunan yang kepemilikannya punya salah satu calon, serta alatalat yang diperlukan untuk melakukan kegiatan hampir dikatakan kurang memadai.

Dengan banyaknya kendala-kendala tersebut, akan sulit bagi Panwaslu untuk melaksanakan tugas yang dibebankan kepada Panwaslu. Karena itu, Panwaslu sangat mengharapkan kerja sama dan kemitraan dengan masyarakat pemantau Pemilu yang diharapkan dapat menjangkau TPS-TPS yang tersebar ke pelosokpelosok. Selain kerjasama dari pemantau pemilu, Panwas juga sangat mengharapkan kerja sama masyarakat luas pada umumnya. Khususnya dalam hal pelaporan pelanggaran-pelanggaran yang terjadi dalam proses pelaksanaan Pemilu.

\section{Upaya Penguatan Peran Panwas dalam Pemilukada Kabupaten Jembrana}

Pasca diundangkannya Undang-Undang

Nomor 22 Tahun 2007 tentang Penyelenggara Pemilu, dimensi pengawasan pemilu mengalami perubahan. Setidaknya dalam konteks eksistensi, institusi pengawas pemilu mengalami peningkatan, baik dalam Undang-Undang Nomor 12 Tahun 2003 maupun Undang-Undang Nomor 32 Tahun 2004 (PP Nomor 6 Tahun 2005) memposisikan panitia pengawas pemilu hanya sebatas instrumen yang bersifat ad-hoc. Adapun dalam Undang-Undang Nomor 22 Tahun 2007, selain istilah Panitia Pengawas Pemilu (Panwaslu) diganti menjadi Badan Pengawas Pemilu (Bawaslu), maka institusi pengawas ini berstatus sebagai instrumen yang bersifat permanen.

Jika ditinjau secara yuridis dari pengaturan dalam Undang-Undang Nomor 22 Tahun 2007, ada beberapa persoalan yang yang dihadapi oleh lembaga pengawas tersebut. Pertama, Kewenangan sebagaimana yang diatur dalam undang-undang sangat kurang mendukung kinerja optimal Panwaslu. Kewenangan yang ada selama ini hanyalah sebagai lembaga pemberi stempel atau pengirim persoalan saja. Sebaiknya kedepan Panwaslu harus dipayungi kewenangan yang lebih luas (bisa sebagai eksekutor), bukan hanya sekedar sebagai wasit atau hakim garis saja, sementara kewenangan untuk memutuskan sanksi pelanggaran pemilu ada di KPU dan Kepolisian.

Terkait dengan kewenangan ini, penguatan Panwaslu dengan penambahan kewenangan seperti hak untuk menyelidiki atau melakukan penyidikan terhadap pelanggaran, sulit dilakukan karena Panwaslu tidak didesain untuk memiliki kewenangan yang demikian (eksekutor), kewenangan tersebut ada pada lembaga lain, sedangkan Panwaslu yang pertama yang bertindak menangani pelanggaranpelanggaran dilapangan, sehingga dengan tidak adanya kewenangan tersebut, dimata masyarakat peran Panwas tidak optimal hanya semacam "macan ompong" saja, padahal punya taring yang tajam.

Keberadaan Panwaslu dengan kewenangan yang demikian memang sangat sulit untuk dapat bekerja secara optimal. Lebih-lebih jika lembaga terkait dengan penanganan pelanggaran pemilu tidak bekerja secara sinergis, maka masyarakat akan begitu saja menumpukkan kelemahan penanganan pelanggaran pemilu kepada Panwaslu tanpa mencoba memahami persoalan yang sebenarnya. Persoalan pelanggaran pemilu merupakan persoalan yang pelik dan memiliki sensitifitas yang besar yang menuntut 
ketulusan, kerja keras dan juga pemahaman secara sosiologis atas pelaku dan budaya di masyarakat dalam penanganannya.

Guna menciptakan pelaksanaan Pemilukada Jembrana yang sukses, aman, tenteram serta untuk menciptakan stabilitas politik yang kondusif, Panwaslu Kabupaten Jembrana bekerjasama dengan Pemkab Jembrana bersama Tim Koordinasi Dukungan Kelancaran Penyelenggaraan Pemilukada yang terdiri dari Polri TNI, dan Satuan Polisi PP saling bersinergi. Dari keempat unsur pengamanan Pemilukada itu, ditempatkan di seluruh TPS Kecamatan. Meski diawal kegiatan sempat terkendala persoalan anggaran operasional, namun pada akhirnya setelah melalui rapat koordinasi antara Kesbangpolinmas dengan Badan Pertimbangan Keuangan Daerah (BPKD), persoalan ini bisa teratasi.

Koordinasi antara seluruh instansi terkait sangat diharapkan maka akan tercipta keamanan dan ketertiban khususnya dalam hal pendistribusian logistik pemilukada. Seluruh instansi yang ada saling mengisi, misalnya jika terjadi masalah sarana transportasi, maka Pemkab Jembrana langsung turun tangan dengan menyediakan sarana tambahan dan berkoordinasi langsung dengan kecamatankecamatan yang ada. Dengan begitu logistik yang diperlukan untuk pemilukada dapat sampai sesuai dengan jadwal yang ditetapkan.

Pemilukada Jembrana memiliki tingkat kerawanan yang perlu diantisipasi, sehingga perlu dilakukan kesepahaman dan kerjasama yang baik antara lembaga pelaksana pemilukada. Memasuki tahapan kampanye, empat pasangan calon Bupati/Wakil Bupati Jembrana, Sentra Penegakan Hukum Terpadu (Sentra Gakkumdu) Polres Jembrana sering melakukan koordinasi dan sosialisasi kepada masyarakat. Meskipun belum menerima adanya laporan, namun seandainya ada laporan, maka Panwaslu akan menindaklanjutinya ke kepolisian dan diproses di Kejaksaan. Meskipun di antara anggota Sentra Gakumdu saling mengenal, namun saat dilakukan gelar perkara, masing-masing anggota memberikan argumentasi yang sangat kritis.

Kesungguhan dalam menjalankan tugas dari seluruh anggota, sesungguhnya didasari keinginan yang sama, yaitu menciptakan Pemilukada Jembrana yang aman, damai dan kondusif, sehingga menghasilkan bupati/wakil bupati yang dapat melaksanakan amanah masyarakat dengan sebaikbaiknya dan menjalankan roda pemerintah dengan program yang terbaik. Masyarakat Jembrana saat ini berharap terjadinya perubahan ke depan dikarenakan masih banyaknya masyarakat miskin, masih banyak pengangguran dan infrastruktur yang perlu terus ditingkatkan.

Selanjutnya, penguatan Panwaslu Kabupaten Jembrana yang selama ini hanya sebagai lembaga yang ad hoc menjadi lembaga yang permanen seperti KPU provinsi dan kabupaten/kota.
Lembaga yang bersifat ad hoc dalam bekerjanya akan menghadapi persoalan yang komplek. Dari aspek personal, para anggota rata-rata muka baru. Mereka membutuhkan waktu yang cukup untuk dapat memiliki pemahaman untuk penyamaan persepsi, visi, misi dan tujuan serta mekanisme kerja. Padahal tuntutan tugas sudah sangat mendesak. Kesulitan ini juga dikarenakan latar belakang mereka sangat heterogen.

Dengan kedudukan sebagai lembaga yang permanen, kemungkinan besar problematik tersebut dapat dihindari, karena dengan para anggota yang lama, maka adanya keberlanjutan dari segi operasional, dalam hal penanganan berkas dan dokumentasi, menghemat waktu yang dibutuhkan dalam melaksanakan sistem pengawasan pemilu, terutama dalam persiapan karena proses tersebut tidak dimulai lagi dari awal, serta tidak harus merekrut dan melatih staf baru yang juga membutuhkan waktu, juga tidak harus membeli peralatan operasional baru setiap kali akan menyelenggarakan pemilukada.

Selain itu, jika dengan ditetapkannya Panwaslu sebagai lembaga yang permanen akan menimbulkan dampak psikologis bagi kesetaraan dengan KPU setempat oleh para anggotanya. Para anggota Panwaslu akan dapat bekerja dengan kesinambungan program dan kondisi personal yang stabil karena lama keberadaannya. Akan tetapi bila dibentuk sebagai lembaga yang permanen, maka Panwaslu bisa dibentuk di dalam organisasi KPU sebagai sebuah unit/bagian yang menangani pengawasan pemilu dan sebagai adalah struktur yang harus dipertahankan.

Persoalan rekrutmen anggota Panwaslu juga menjadi aspek penting. Rekrutmen anggota Panwaslu ke depan seharusnya dilakukan sendiri oleh Bawaslu bagi Panwas provinsi dan Panwas provinsi bagi anggota Panwas kabupaten/kota. Jika hal ini dapat terjadi, maka anggota Panwas terpilih minimal akan dapat memenuhi kualifikasi personal, sosial, intelektual yang dibutuhkan sebagai anggota Panwaslu. Selama ini, rekrutmen terhadap calon anggota Panwaslu kabupaten/kota, misalnya dilakukan oleh KPU setempat. Proses seleksi administratif selama ini dilakukan oleh KPU setempat dengan hanya mendasarkan pada kapasitas intelektual berupa hasil tes. Setelah ditetapkan oleh KPU, sejumlah peserta yang ditetapkan kemudian dilanjutkan seleksinya oleh Panwas provinsi untuk melihat kapasitas personal, kelembagaan serta komitmen dalam membangun Panwaslu yang mandiri dan profesional ke depan. Dengan demikian, bagi panwas rekruitmen calon anggota ini masih adanya campur tangan KPU, sehingga panwas tidak dapat bekerja seoptimal mungkin.

Ke depan seleksi harus sepenuhnya dilakukan oleh Panwas sendiri secara berjenjang atau bisa juga dilakukan oleh tim seleksi independen dan fit and proper test-nya dilakukan panwas atasnya. 
sehingga tidak adanya campur tangan KPU sebagaimana diatur dalam Pasal 93, Pasal 94, Pasal 95 Undang-Undang Penyelenggara Pemilu. Jika dalam proses seleksi pihak selektor tidak konsisten dan menyalahgunakan kewenangan ke depan akan sangat nampak dari kinerja Panwasu yang telah direkrut sendiri. Karena merekalah yang sangat paham akan kebutuhan dan kapasitas anggota Panwas yang direkrut. Idealnya, rekruitmen anggota panwas diisi oleh orang-orang yang punya integritas, dedikasi tinggi, kredibel, kapabel dan memiliki komitmen moral kuat untuk bersikap independen melalui proses perekrutan politik yang dilakukan secara selektif, fair serta terbuka sehingga kinerjanya memiliki kredibilitas yang baik dan dapat dipertanggungjawabkan di mata publik dan bekerja secara profesional sebagaimana mestinya

Aspek lainnya yang penting bagi penguatan peran Panwaslu adalah hubungan antar tingkatan Panwas tersebut harus ditegaskan. Selama ini ketentuan dalam undang-undang tidak mengaturnya. Setiap tingkatan Panwas tentu akan menampilkan gaya dan kinerja yang berbeda-beda yang jika tidak sesuai dengan harapan dan tuntutan justru akan melemahkan Panwas itu sendiri. Sebagai bentuk dari akuntabilitas publik kedepan Panwaslu dari setiap tingkatan yang jika kelak dipermanenkan dapat menjadi lembaga objek gugatan terutama terkait dengan keputusan yang dikeluarkannya sebagaimana yang terjadi di KPU selama ini. Keberadaan PPL dan Panwaslucam selama ini juga tidak jelas hubungannya dengan Panwaslu di atasnya. Kedepan dua tingkatan pengawas ini sebaiknya diposisikan sebagai bagian/perangkat pendukung Panwas kabupaten dan kota. Salah satu alasannya terkait dengan level lembaga pemegang priwitan dalam pelanggaran pemilu, yaitu KPU dan Kepolisian, sedangkan Panwaslu kabupaten dan kota ke atas memiliki hubungan yang hirarki dan jelas.

Dasar dari upaya penguatan terhadap Pengawas pemilu dalam melaksanakan tugas pengawasan tersebut adalah dilakukannya upaya judicial review atas undang-undang tentang Penyelenggara Pemilu (Undang-Undang Nomor 22 Tahun 2007). Melalui judicial review (JR) atas undang-undang tersebut diharapkan berbagai persoalan yang membelenggu dan menghambat optimalisasi kerja Panwaslu dapat diminimalisir dan ditingkatkan sebagaimana mestinya. Adapun mengenai hak-hak pemilih sebagaimana tercantum di dalam Undang-Undang Nomor 32 Tahun 2004, meliputi hak bebas menghadiri kampanye, hak memperoleh visi, misi dan program secara tertulis dari kandidat, hak atas kampanye yang sopan, tertib, edukatif, hak atas akses informasi mengenai Pilkada melalui media massa, hak memperoleh informasi terbuka mengenai hasil audit dana kampanye 3 hari setelah KPUD menerimanya dari akuntan publik, hak hari libur pada hari pemilihan, hak memperoleh informasi mengenai tim kampanye, hak memperoleh informasi mengenai hasil audit dana kampanye dan hak memperoleh informasi mengenai hasil Pilkada, selain itu masyarakat juga memiliki hak terbebas dari praktik politik uang dan hak terbebas dari penyelewengan penggunaan fasilitas publik oleh pejabat publik.

Untuk itu, Panwaslu Kabupaten Jembrana menyiapkan langkah-langkah strategis dalam mengantisipasi titik-titik rawan yang akan terjadi dalam pelaksanaan pilkada agar pada pemilihan kepala daerah terjadi peningkatan kualitas pemilihan. Pertama, mengawasi KPUD, PPK dan petugas PPS untuk tidak memanipulasi hasil penghitungan. Pengalaman pada pencoblosan pemilu lalu yang banyak terdapat kejanggalan-kejanggalan dalam penghitungan suara harus menjadi pelajaran bagi kita dan diantisipasi. Kedua, membuat sebuah petunjuk yang sistematis dan praktis agar Panwaslu di tingkat bawah bisa bertindak secara cepat apabila menemui pelanggaran-pelanggaran pada pelaksanaan Pilkada. Ketiga, mempertegas aturan dan sanksi mengenai pelanggaran terhadap penggalangan massa, pawai dan membayar massa. Keempat, mempertegas aturan yang melarang penggunaan fasilitas pemerintah/negara untuk keperluan kampanye. Yang terakhir dan saat ini marak terjadi adalah mengawasi agar isi kampanye tidak menfitnah atau melakukan kampanye negatif. Ternyata membuka aib orang dan mejelekkan kandidat lain tanpa disertai dengan argumen dan bukti yang kuat sudah menjadi kebiasaan dalam setiap suksesi politik, hal ini harus dihindari dalam upaya membangun upaya politik santun dan demokrasi di tingkat lokal.

Dengan demikian, untuk meningkatkan citra peran Panwaslu Jembrana, maka Panwaslu Jembrana melakukan upaya-upaya untuk memaksimalkan perannya dalam pengawasan pilkada, di antaranya: sosialisasi yang dilakukan panwaslu, untuk memberi pengetahuan kepada masyarakat tentang pilkada dan kemungkinan pelanggaran-pelanggaran yang terjadi; pengawasan aktif, untuk mencegah terjadinya pelanggaran pilkada, dan melaporkannya bila terjadi; memaksimalkan pengawasan masyarakat dengan melibatkan tokoh-tokohnya untuk membantu melakukan pengawasan terhadap pelanggaran yang mungkin terjadi di sekitar wilayah Kabupaten Jembrana.

\section{SIMPULAN}

Dari uraian pengalaman Pemilukada di Kabupaten Jembrana, ada beberapa persoalan yang dihadapi oleh Panwaslu, yakni: (1) kewenangan sebagaimana yang diatur Undang-Undang sangat kurang mendukung kinerja optimal Panwaslu, karena kewenangan yang ada hanyalah sebagai lembaga pemberi stempel atau pengirim persoalan saja; (2) Panwaslu Kabupaten Jembrana yang selama ini merupakan lembaga ad hoc dalam bekerjanya akan menghadapi persoalan yang komplek; (3) pola 
rekrutmen anggota Panwaslu Kabupaten Jembrana belum memenuhi kualifikasi personal, sosial, intelektual yang dibutuhkan sebagai anggota Panwaslu; dan (4) belum ada penegasan hubungan antar tingkatan Panwaslu Kabupaten Jembrana dengan Panwaslu Provinsi Bali, sehingga melemahkan Panwaslu itu sendiri.

Oleh karena itu, perlu upaya penguatan fungsi Panwaslu, seperti: memperluas kewenangan Panwaslu; pembentukannya bukan sebagai lembaga ad hoc; dan pola rekrutmennya diperketat dengan persyaratan yang memadai.

\section{DAFTAR PUSTAKA}

Amirudin dan Zaini Bisri, 2006. Pilkada Langsung Problem dan Prospek, Penerbit Pustaka Pelajar, Jakarta.

Bagir Manan, 2003. DPR, DPD, MPR dalam UUD 1945 yang baru, FH UII Press, Jakarta.

Donni Edwin, 2005. Pilkada Langsung: Demokratisasi Daerah dan Mitos Good Governance, Partnership, Jakarta.

Joko Prihatmoko, 2005. Pemilihan Kepala Daerah Langsung Filosofi Sistem dan Problem Penerapan di Indonesia, Pustaka Pelajar, Jogyakarta.

Jimly Asshiddiqie, 2002. Konsolidasi Naskah UUD 1945 Setelah Perubahan Keempat, Pusat Studi Hukum Tata Negara UI.

Koirudin, 2004. Partai Politik dan Agenda Transisi Demokrasi, Pustaka Fajar, Jogyakarta.

Laporan Penelitian Tim PDN P3DI, 2010. Pemilihan Umum Kepala Daerah Bupati/Walikota Di Provinsi Riau, Setjen DPR-RI.

Leo Agustino, 2005. Politik dan Otonomi Daerah, Untirta Press, Banten.

Mahfud M, 1999. Hukum dan Pilar-Pilar Demokrasi, Gama Media, Jogyakarta.

Miriam Budiardjo, 1982. Partisipasi dan Partai Politik, Garamedia, Jakarta.

Robert Dahl, 1982. Dilema Demokrasi Pluralis, Rajalawi, Jakarta.

Sugiyono, 2005. Memahami Penelitian Kualitatif, Penerbit CV Alfabeta, Bandung.

Undang-Undang Nomor 32 Tahun 2004 tentang Pemerintahan Daerah

Undang-Undang Nomor 22 Tahun 2007 tentang Penyelenggaraan Pemilu.

International IDEA, 2000. Demokrasi dan Konflik Yang Mengakar: Sejumlah Pilihan Untuk Negosiator, Seri Buku Pegangan Internasional IDEA, Jakarta.

http://www.bawaslu.go.id/berita/35/tahun/2010/bulan/0 7/tanggal/21/id/1504/, diakses tanggal 12 Desember 2010.

http://new-media.kompasiana.com/2010/04/19/evoting-belajar-dari-kabupaten-jembrana/, diakses tanggal 12 Desember 2010.

http://www.jembranakab.go.id/pengumuman/ Bab2.pdf, di akses tanggal 12 Desember 2010. http://www.kpujembrana.com/index.php/home/111pengundian-nomer-urut-pasangan-calon, diakses tanggal 14 Desember 2010. 